\title{
Psychopathology in adults with 22q11 deletion syndrome and moderate and severe intellectual disability
}

Citation for published version (APA):

Evers, L. J. M., van Amelsvoort, T. A. M. J., Candel, M. J. J. M., Boer, H., Engelen, J. J. M., \& Curfs, L. (2014). Psychopathology in adults with 22q11 deletion syndrome and moderate and severe intellectual disability. Journal of Intellectual Disability Research, 58(10), 915-925. https://doi.org/10.1111/jir.12117

Document status and date:

Published: 01/10/2014

DOI:

10.1111/jir.12117

Document Version:

Publisher's PDF, also known as Version of record

Document license:

Taverne

Please check the document version of this publication:

- A submitted manuscript is the version of the article upon submission and before peer-review. There can be important differences between the submitted version and the official published version of record.

People interested in the research are advised to contact the author for the final version of the publication, or visit the DOI to the publisher's website.

- The final author version and the galley proof are versions of the publication after peer review.

- The final published version features the final layout of the paper including the volume, issue and page numbers.

Link to publication

\footnotetext{
General rights rights.

- You may freely distribute the URL identifying the publication in the public portal. please follow below link for the End User Agreement:

www.umlib.nl/taverne-license

Take down policy

If you believe that this document breaches copyright please contact us at:

repository@maastrichtuniversity.nl

providing details and we will investigate your claim.
}

Copyright and moral rights for the publications made accessible in the public portal are retained by the authors and/or other copyright owners and it is a condition of accessing publications that users recognise and abide by the legal requirements associated with these

- Users may download and print one copy of any publication from the public portal for the purpose of private study or research.

- You may not further distribute the material or use it for any profit-making activity or commercial gain

If the publication is distributed under the terms of Article 25fa of the Dutch Copyright Act, indicated by the "Taverne" license above, 


\title{
Psychopathology in adults with 22q I deletion syndrome and moderate and severe intellectual disability
}

\author{
L. J. M. Evers, ${ }^{1,2}$ T. A. M. J. van Amelsvoort,, ${ }^{3,4,5}$ M. J. J. M. Candel, ${ }^{6,7}$ H. Boer, ${ }^{8}$ \\ J. J. M Engelen' \& L. M. G. Curfs $2,7,9,10$ \\ I MFCG, Koraalgroup, Heel, The Netherlands \\ 2 Governor Kremers Centre, Maastricht University Medical Centre, Maastricht, The Netherlands \\ 3 Department of Psychiatry and Psychology, Maastricht University, Maastricht, The Netherlands \\ 4 Mondriaan Mental Healthcare, Heerlen, The Netherlands \\ 5 Virenze Mental Healthcare, Gronsveld, The Netherlands \\ 6 Department of Methodology and Statistics, Maastricht University, Maastricht, The Netherlands \\ 7 CAPHRI, School for Public Health and Primary Care, Maastricht University, Maastricht, The Netherlands \\ 8 Brooklands Hospital, Janet Shaw Clinic, Birmingham, UK \\ 9 Department of Clinical Genetics, Maastricht University Medical Centre, Maastricht, The Netherlands \\ 10 GROW School for Oncology and Developmental Biology, Maastricht University, Maastricht, The Netherlands
}

\begin{abstract}
Background 22qiI deletion syndrome (22qIIDS) is associated with mild or borderline intellectual disability (ID). There are hardly any reports on subjects with 22qIIDS with moderate or severe ID, and therefore its behavioural and psychiatric characteristics are unknown.

Method We describe behavioural and psychiatric characteristics of 33 adults with 22qIIDS and a Full-Scale IQ (FSIQ) below 55. Participants were divided into two groups: one group having a FSIQ $\leq 55$ caused by intellectual decline $(n=2 \mathrm{I})$ and one group with a FSIQ $\leq 55$ who had always functioned at this level $(n=\mathrm{I} 2)$.

Results High scores on psychopathology sub-scales were found for both subgroups. 22qIIDS patients with intellectual decline showed higher rates of
\end{abstract}

Correspondence: Mr L. J. M. Evers, Koraalgroep, MFCG, Panheelderweg 3, 6097 AH Heel, The Netherlands (e-mail: revers@stanna.koraalgroep.nl). co-morbid psychopathology, particularly psychosis. Furthermore, psychosis and intellectual decline were positive correlated.

Conclusion This is the first report addressing adult patients with 22qIIDS and moderate to severe ID. Overall we found high levels of psychopathology with higher scores of psychopathology in the intellectual decline group. Life time psychosis seems to be related to deterioration.

Keywords 22qII deletion syndrome, intellectual decline, IQ, psychopathology, velocardiofacial syndrome

\section{Introduction}

22qII deletion syndrome (22qIIDS), is the most common recurrent copy-number variant disorder caused by a microdeletion in chromosome band 22 III.2 occurring with an incidence of $\mathrm{I}$ in 4000 (Oskarsdottir et al. 2004; McDonald McGinn \&

(C) 2014 MENCAP and International Association of the Scientific Study of Intellectual and Developmental Disabilities and John Wiley \& Sons Ltd 
Sullivan 20II). It is also known as Shprintzen's syndrome or velocardiofacial syndrome (VCFS). Earlier reports of conotruncal anomaly face syndrome, Cayler's syndrome, Takao's syndrome, Sedlačková syndrome, velofacial syndrome and Di-George syndrome turned out to be caused by the same deletion (McDonald McGinn \& Sullivan 20II). Characteristic clinical features include palatal anomalies, cardiac anomalies, hypo- or aplasia of the thymus, hypoplasia of the parathyroid and typical facial features. The physical appearance is known to be highly variable (McDonald-McGinn et al. 1999; Shprintzen et al. 2005; Shprintzen 2008). Approximately half of all subjects with 22qIIDS have a normal to borderline intelligence (Swillen et al. I997; Henry et al. 2002; Antshel et al. 2008; Niklasson \& Gillberg 20I0) and if an intellectual disability (ID) is present, this is usually mild (Swillen et al. 1997; De Smedt et al. 2007). The presence of a severe or profound ID is thought to be rare (Swillen et al. I997). Patients with 22qIIDS have a characteristic intelligence profile with poor visual spatial skills, planning ability and abstract reasoning (Swillen et al. I999; Henry et al. 2002). Besides the physical and intellectual characteristics, several psychiatric disorders have been reported to be common in children and adolescents with 22qIIDS including autism spectrum disorders (ASD) ( $14 \%-50 \%)$, attention-deficit/hyperactivity disorder (ADHD) $(3 \%-46 \%)$, specific and social phobias $(23 \%-6 \mathrm{r} \%)$, generalised anxiety disorder $(\mathrm{I} 7 \%-29 \%)$, separation anxiety disorder (16\%$2 \mathrm{I} \%$ ), oppositional defiant disorder ( $16 \%-2 \mathrm{I} \%$ ), obsessive-compulsive disorder (OCD) $(4 \%-33 \%)$, major depressive disorder and dysthymia (IO\%20\%) and bipolar disorder (0-64\%) (Papolos et al. I996; Arnold et al. 200I; Feinstein et al. 2002; Gothelf et al. 2004, 2009; Antshel et al. 2006, 2007; Vorstman et al. 2006; Niklasson et al. 2009; McDonald McGinn \& Sullivan 20I i; Philip \& Bassett 20II). Up to $30 \%$ of the patients with 22qIIDS develop psychotic disorders including schizoaffective disorder and schizophrenia in late adolescence and early adulthood (Murphy et al. I999; Bassett et al. 2003; Gothelf et al. 2005, 2009; Stevens \& Murphy 2005; Boot et al. 20I Ib). Therefore, studying this syndrome offers a unique opportunity to increase our understanding of the mechanisms underlying psychiatric disorders. Only few patients with 22qIIDS and moderate to severe ID [Full-Scale IQ (FSIQ) < 55] have been described in the literature (Gerdes et al. I999; Evers et al. 2009). The aim of this explorative study was to gain a better insight into the psychiatric phenotype in adults with 22 qIIDS who are functioning in the moderate to severe ID range. This will expand our knowledge on the cognitive and psychiatric phenotype of 22qIIDS. In addition it may aid the clinician who is working with these often challenging patients.

\section{Method}

The study was approved by the Medical Ethics Committee of the University of Maastricht, Maastricht, the Netherlands.

\section{Study population}

Participants were recruited through a Dutch psychiatric 22qIIDS outpatient clinic and through physicians specialised in ID. Subjects with a confirmed deletion in chromosome band 22qII.2 and a present FSIQ $\leq 55$ were included. Those aged under I8 years and over the age of 65 years were excluded, as well as participants with physical disorders affecting brain function like suspicion of major neurological disorders like brain tumours or stroke. A number of participants gave written consent, and where participants were not able to do so (the majority), consent was obtained from caregivers.

Thirty-three participants [ 15 women $(45.5 \%)$, I8 men $(54.5 \%)]$ with confirmed 22 qIIDS participated in this study. The mean age of participants was 40 years (SD = II, range I9-59 years). Thirty-one $(93.9 \%)$ of the participants lived in institutions and $6 . \mathrm{I} \%(n=2)$ lived at home with their family. Socio-demographic characteristics are presented in Table I. All participants had a present level of functioning below FSIQ 55. Presence of psychosis during life was obtained out of data from medical files and/or positive score for psychosis on the Mini PAS-ADD (Psychiatric Assessment Schedules for Adults with Developmental Disabilities). Premorbid intellectual functioning was determined preferable at young adult age by data from medical files. Based on premorbid intellectual functioning 


\begin{tabular}{|c|c|c|c|}
\hline & $\begin{array}{l}\text { Intellectual decline } \\
(n=21)\end{array}$ & $\begin{array}{l}\text { No intellectual decline } \\
(n=12)\end{array}$ & $P$-values \\
\hline Gender & Male: I0; female: II & Male: 8; female: 4 & 0.305 \\
\hline Age: mean $\pm S D$ & $41.81 \pm 7.393$ & $39.00 \pm 14.87$ & 0.550 \\
\hline Premorbid IQ: mean \pm SD & $74.2 \pm 7.5$ & $43.7 \pm 8.1$ & $0.000 *$ \\
\hline Age at assessment of premorbid IQ: mean \pm SD (range) & $18.2 \pm 6.8(6-27)$ & $17.5 \pm 6.9(7-32)$ & 0.769 \\
\hline $\begin{array}{l}\text { Duration between assessment of premorbid functioning } \\
\text { and present assessment: mean } \pm S D \text { (range) }\end{array}$ & $23.6 \pm 9.8(8-39)$ & $21.5 \pm 11.4(14-48)$ & 0.585 \\
\hline V-S, communication: mean $\pm \mathrm{SD}^{\dagger}$ & $44.2 \pm 15,3$ & $35.2 \pm 15.9$ & 0.117 \\
\hline V-S, daily living skills: mean $\pm \mathrm{SD}^{\dagger}$ & $48.9 \pm 13.5$ & $45.8 \pm 16.8$ & 0.565 \\
\hline V-S, socialisation: mean $\pm \mathrm{SD}^{\dagger}$ & $23.3 \pm 10.3$ & $27.3 \pm 16.6$ & 0.398 \\
\hline V-S, motor skills: mean $\pm \mathrm{SD}^{\dagger}$ & $38.2 \pm 13.0$ & $33.6 \pm 14.1$ & 0.345 \\
\hline V-S, composite score: mean $\pm \mathrm{SD}^{\dagger}$ & $39.4 \pm 12.1$ & $35.3 \pm 15.6$ & 0.406 \\
\hline Estimated FSIQ (Vineland-S composite scores): mean \pm SD & $30.2 \pm 8.0$ & $27.3 \pm 10.7$ & 0.383 \\
\hline FSIQ drop ${ }^{\ddagger}:$ mean \pm SD & $43.1 \pm 14.0$ & $15.3 \pm 8.4$ & $0.000 *$ \\
\hline History of Psychotic Disorder & $20(95 \%)$ & $2(15 \%)$ & $0.000 *$ \\
\hline Use of antipsychotics & 17 (81\%) & $7(58 \%)$ & 0.171 \\
\hline Use of antidepressants & $6(29 \%)$ & $3(25 \%)$ & 0.831 \\
\hline Use of mood stabilisers & II (52\%) & $4(33 \%)$ & 0.305 \\
\hline \multirow[t]{2}{*}{ Deletion } & De novo: 21 & De novo: 10 & \\
\hline & Familial: I & Familial: I & \\
\hline
\end{tabular}

$* P$-value $\leq 0.007$ (after Bonferroni adjustment).

† Vineland-S, in developmental age (in months).

* Drop Full-Scale IQ (FSIQ): premorbid FSIQ minus estimated FSIQ based on Vineland-S scores.

subjects were divided into two groups: an 'intellectual decline group' $(n=2 \mathrm{I})$ : patients with a

FSIQ $>55$ in the past, but who were functioning at a level of FSIQ $\leq 55$ at time of inclusion, and a 'no intellectual decline group' ( $n=\mathrm{I} 2)$ : patients with a FSIQ $\leq 55$ who had a premorbid FSIQ $\leq 55$.

\section{Clinical and behavioural measures}

The individuals with 22qIIDS and their main caretakers were visited at home. They were interviewed by a psychiatrist with special expertise in ID (lead author). The following instruments were administered:

\section{Vineland-screener}

The translated version (Dutch) of the Vineland screener (Vineland-S) (Scholte et al. 2008) was used to obtain information about adaptive functioning. It is developed for children, adolescents and adults with a developmental age up to 6 year. It is suitable for use in both research and clinical settings (Sparrow et al. 2008). This instrument, completed by a primary caregiver, provides a practical indication of the adaptive functioning related to age (van Duijn et al. 2009). Vineland instruments have been used in adults with a moderate to severe ID and various genetic disorders (Wulffaert et al. 2009; Adams \& Oliver 2010). Because standard intelligence instruments are not suitable in this range of intelligence we chose for the Vineland screener. Outcomes of the Vineland-S developmental age were used to give an estimation of FSIQ (Kraijer \& Plas 2006). Comparison of intelligence measured with Wechsler scales and functioning determined with Vineland screener has been described before in 22qiiDS (Antshel et al. 2005). Internal consistency of this instrument (Cronbach's alpha) varied from 0.96 to 0.99 with a test-retest correlation varying from 0.90 and to 0.96 (van Duijn et al. 2009).

(C) 20I4 MENCAP and International Association of the Scientific Study of Intellectual and Developmental Disabilities and John Wiley \& Sons Ltd 
L. J. M. Evers et al. • 22qIIDS and low intelligence

Table 2 Mini PAS-ADD and ABCL scores

\begin{tabular}{|c|c|c|c|}
\hline Mini PAS-ADD score ${ }^{\dagger}$ & $\begin{array}{l}\text { Intellectual decline } \\
\text { mean } \pm \text { SD }\end{array}$ & $\begin{array}{l}\text { No intellectual decline } \\
\text { mean } \pm \text { SD }\end{array}$ & $P$-value \\
\hline Depression (I0) & $8.38 \pm 7.24$ & $3.33 \pm 3.11$ & 0.010 \\
\hline Anxiety disorder (7) & $3.81 \pm 4.86$ & $0.83 \pm 2.04$ & 0.020 \\
\hline Mania/hypomania (8) & $2.14 \pm 2.50$ & $0.75 \pm 0.75$ & 0.070 \\
\hline Obsessive-compulsive disorder (3) & $1.29 \pm 1.95$ & $0.50 \pm 1.45$ & 0.234 \\
\hline Psychosis (2) & $2.00 \pm 2.15$ & $0.25 \pm 0.62$ & $0.002 *$ \\
\hline Unspecified (6) & $3.29 \pm 2.43$ & $0.58 \pm 0.79$ & $0.000 *$ \\
\hline Autism spectrum N (4) & $5.81 \pm 1.60$ & $5.33 \pm 1.92$ & 0.450 \\
\hline Autism spectrum $\mathrm{P}(\mathrm{I})$ & $1.57 \pm 0.87$ & $1.42 \pm 0.79$ & 0.616 \\
\hline Autism spectrum R (3) & $1.43 \pm 0.98$ & $1.42 \pm 1.08$ & 0.974 \\
\hline \multicolumn{4}{|l|}{ ABCL/syndrome scale } \\
\hline Anxious/depressed & $67.43 \pm 14.28^{\#}$ & $60.50 \pm 8.12$ & 0.134 \\
\hline Withdrawn & $75.38 \pm 11.05^{\# \#}$ & $70.92 \pm 6.37^{\# \#}$ & 0.151 \\
\hline somatic complaints & $59.48 \pm 6.20$ & $59.67 \pm 7.68$ & 0.938 \\
\hline Thought problems & $74.10 \pm 9.23^{\# \#}$ & $69.75 \pm 14.05^{\#}$ & 0.291 \\
\hline Attention problems & $71.52 \pm 8.52^{\# \#}$ & $65.17 \pm 6.85^{\#}$ & 0.035 \\
\hline Aggressive behaviour & $69.33 \pm 13.26^{\#}$ & $62.75 \pm 21.02$ & 0.277 \\
\hline Rule breaking behaviour & $64.71 \pm 6.57$ & $61.00 \pm 4.79$ & 0.097 \\
\hline Intrusive & $60.76 \pm 10.20$ & $59.75 \pm 7.55$ & 0.767 \\
\hline \multicolumn{4}{|l|}{ ABCL/DSM oriented scale } \\
\hline Depressive problems & $67.86 \pm 9.99^{\#}$ & $63.33 \pm 8.86$ & 0.203 \\
\hline Anxiety problems & $59.10 \pm 9.46$ & $57.75 \pm 9.42$ & 0.697 \\
\hline Somatic problems & $58.19 \pm 6.88$ & $59.25 \pm 7.68$ & 0.686 \\
\hline Avoidant problems & $73.10 \pm 9.03^{\# \#}$ & $69.58 \pm 4.68^{\#}$ & 0.152 \\
\hline ADHD problems & $67.90 \pm 10.22^{\#}$ & $62.83 \pm 6.85$ & 0.136 \\
\hline Antisocial problems & $65.14 \pm 8.97^{\#}$ & $60.67 \pm 8.96$ & 0.178 \\
\hline
\end{tabular}

$* P \leq 0.002$ (after Bonferroni adjustment).

${ }^{\dagger}$ In brackets: threshold score when indicative for diagnosis.

${ }^{\ddagger} \mathrm{ABCL}$ scores: <65: normal; 65-70: borderline clinical range ${ }^{\#}$; $>70$ : clinical range $\mathrm{e}^{\# \#}$.

Mini PAS-ADD, Mini Psychiatric Assessment Schedules for Adults with Developmental Disabilities; ABCL, Adult Behavioral Check List; DSM, Diagnostic and Statistical Manual of Mental Disorders; ADHD, attention-deficit/hyperactivity disorder.

\section{Mini PAS-ADD}

The Mini PAS-ADD, a semi-structured interview for psychiatric disorders in people with an ID (Prosser et al. 1998), was used to provide reliable information on symptoms and to obtain psychiatric diagnoses. Outcomes scores can be dichotomised applying threshold scores when indicative for diagnosis (see Table 2). All interviews were carried out by an experienced psychiatrist (lead author). Recent research into the psychometric properties showed the sensitivity to be $100 \%$ and the specificity to be $77 \%$ (Devine et al. 2010). Cronbach's alpha varied from 0.55 for unspecified disorders to 0.95 for autism (Prosser et al. 1998).
Adult Behavioral Check List (ABCL)

The Adult Behavioral Check List (ABCL) (Achenbach \& Rescorla 2003) was administered to assess prevalence and severity of any behavioural problems. The 134-item questionnaire was completed by the primary caregivers of the participants. Problematic statements were scored by a carer or family member who knew the person well, on a three-level rating scale ('not true', 'somewhat or sometimes true' and 'very true'). Following analysis, eight syndrome scales were distinguished (anxious/ depressed, withdrawn, somatic complaints, thought problems, attention problems, aggressive behaviour, rule-breaking behaviour and intrusive) and six DSM-oriented (Diagnostic and Statistical Manual

(C) 20I4 MENCAP and International Association of the Scientific Study of Intellectual and Developmental Disabilities and John Wiley \& Sons Ltd 
of Mental Disorders) scales: depressive problems, anxiety problems, somatic problems, avoidant personality problems, ADHD problems and antisocial personality problems). Internal consistency of the ABCL (Cronbach's alpha) varied from 0.70 to 0.97 with a test-retest correlation varying 0.73 and 0.92 (Achenbach \& Rescorla 2003).

\section{Use of psychotropic drugs}

The use of psychotropic drugs was noted and classified as antipsychotics, antidepressants and mood stabilisers (Table I).

\section{Statistical analyses}

Socio-demographic data were examined using independent t-tests and Chi-square analysis to determine whether both groups differed with regards to age, gender and present FSIQ. Between-group comparisons were carried out to investigate differences between the deterioration group and the stable low IQ group. We used independent t-tests for all scores on the Mini PAS-ADD and ABCL that met criteria for a normal distribution. Mann-Whitney $U$-tests were used in case scores were not normally distributed. To correct for multiple comparisons (Bonferroni adjustment) the significance level for testing was set at $\alpha=0.007$ (demographics) and $\alpha=0.002$ (Mini PAS-ADD and ABCL). A twoway between-group analysis of variance was conducted to explore the impact of gender on outcomes of psychopathology in both groups. For the correlation presence of psychosis during life and IQ drop and the correlation between present IQ and use of antipsychotics we performed a Spearman Rank Order correlation coefficient. Pearson product-moment correlation coefficients were performed to analyse (I) the relation between the interval between first intellectual assessment and present intellectual assessment and extend of intellectual decline, and (2) the relation of present FSIQ and Mini PAS-ADD scores for depression, psychosis, anxiety and unspecified problems.

\section{Results}

\section{Participants}

There were no significant between-group differences in gender, age and recently estimated FSIQ
(Table I). Eighteen subjects out of 2 I ( $86 \%$ ) of the deterioration group were on antipsychotic medication; in the stable low IQ group 6 out of 12 subjects $(50 \%)$ took antipsychotic medication $(P=0.027)$.

Figure I shows distributions of decline in individuals of the two groups showing that they are distinct groups.

\section{Previous methods of intelligence assessment}

Of eight patients (all in the 'intellectual decline' group) intelligence tests were not available. Their premorbid intelligence was very conservative estimated based on their school and/or work history. Of I2 patients (five of the 'intellectual decline' group and seven of the 'intellectual stable' group) intelligence was assessed with a variety of test including WISC $(n=5)$, Vineland $(n=\mathrm{I})$, GIT $(n=\mathrm{I})$, WAIS $(n=3)$, Peabody $(n=\mathrm{I})$ and WPPSI $(n=\mathrm{I})$. Of I3 patients (eight of the 'intellectual decline' group and five out of the 'intellectual stable' group) an IQ score was found in medical files, but no method was mentioned.

\section{Psychopathology (Table 2)}

Scores on the Mini PAS-ADD show that symptoms of depressive, psychotic and unspecified disorders were significantly more present in the deterioration group. The symptoms of anxiety disorders on the Mini PAS-ADD $(P=0.02)$ and attention problems on the ABCL $(P=0.035)$ were marginally significant between the two groups, all symptoms occurring more often in the deterioration group. Those with cognitive deterioration were more likely to have a history of a psychotic disorder $(P=0.000)$. The relation between lifetime psychosis (yes/no) and IQ drop was investigated using Spearman Rank Order correlation coefficient. There was a strong positive correlation between the two variables, rho $=0.662, n=33$, $P=0.000$, with presence of lifetime psychosis associated with a larger levels of IQ drop. The relation between present FSIQ and psychopathology was investigated using a Pearson productmoment correlation coefficient between the Mini PASS-ADD scores depression, anxiety, psychosis and unspecified problems (those scored in clinical 


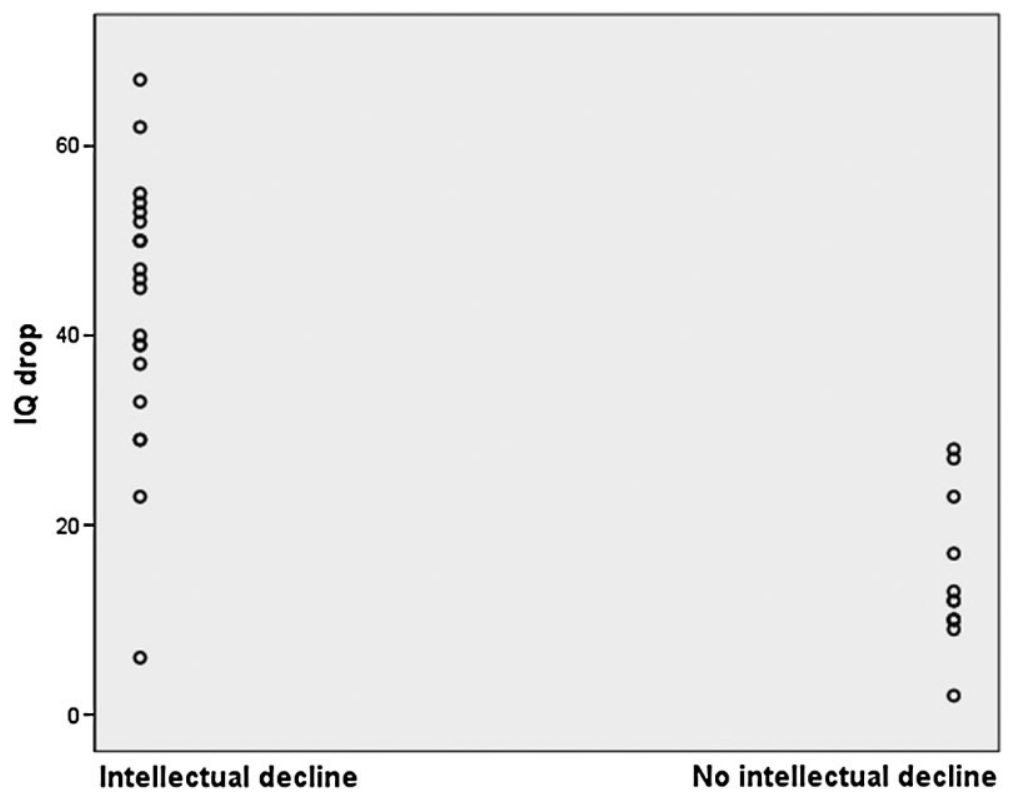

Figure I Scatter plot showing Full-Scale IQ (FSIQ) decline in two groups. ranges) with present FSIQ. None of them showed a correlation $(r=0.257, P=0.149 ; r=0.066$, $P=0.716 ; r=0.332, P=0.059 ; r=0.047$, $P=0.796)$.

\section{Gender differences}

On the ABCL we found a significant group by gender interaction for aggressive behaviour $(P=0.015)$. In the 'intellectual decline' group men showed less aggression $(P=0.04)$ compared with women, whereas in the 'no intellectual decline' group there were no gender differences on ABCL scores. In the 'intellectual decline' group women scored higher on psychotic symptoms compared with men $(P=0.02 \mathrm{I})$, whereas in the 'no intellectual decline' group there was no difference between men and women. In addition, there was a significant group by gender interaction for the ASS-N score (Autism Spectrum Score - social interaction) $(P=0.026)$, female in the intellectual decline group showed less social interaction problems compared with the female in the no intellectual decline group, and the men in the deterioration group scored showed more social interaction problems compared with the men in de 'no intellectual decline' group.

\section{IQ drop}

The relation between the interval of the first assessment and present assessment and extend of decline was investigated using Pearson product-moment correlation coefficient. There was a strong positive relation $(r=0.38, P=0.027)$ when performed in all 33 patients. When performed only on the 'intellectual decline group' the correlation increases ( $r=0.5 \mathrm{I}, P=0.017)$. Correlation in the 'no intellectual decline' group was not significant $(r=0.48$, $P=0$. II2).

\section{Discussion}

This is the first study that describes psychopathology in patients with 22qIIDS and a moderate to profound ID.

\section{Psychopathology}

Overall we found high levels of psychopathology. However when dividing the group in those who with premorbid IQ $<55$ and those with premorbid IQ > 70 and subsequent cognitive decline we observed more psychopathology in the latter group. On the Mini PAS-ADD, a striking difference was

(C) 2014 MENCAP and International Association of the Scientific Study of Intellectual and Developmental Disabilities and John Wiley \& Sons Ltd 
observed between the two groups for symptoms of depression, psychosis and unspecified disorders (including memory and concentration problems, restlessness, sleep problems and anhedonia), with scores being significantly higher in the deterioration group. Scores on the ABCL, however, did not reach significant differences between both groups for depressive and thought problems. One of the reasons for this may be that the ABCL does not score for the same clusters as the Mini PAS-ADD. Items scoring for depression and anxiety can mimic symptoms as seen in ASD. We found high scores on the Mini PAS-ADD in domains of ASD in both groups (up to $92 \%$ ), especially on social interaction scale (scale $\mathrm{N}$ of the Mini PAS-ADD) and communication problems (scale $\mathrm{P}$ of the Mini PAS-ADD), which is higher than reported in previous studies (44\%-50\%) (Vorstman et al. 2006; Niklasson et al. 2009) which were all done in children with 22qIIDS. High scores on scale R of the ASD domains on the Mini PAS-ADD (repetitive and stereotype behaviour) were less common than social interaction problems and communication problems. Bruining et al. (2010) suggested that ASD in 22qIIDS shows less autistic symptom variance compared with ASD not associated with 22qIIDS. They suggest that the influence of a specific genetic variant (such as 22qIIDS) leads to a typical ASD subtype with lower autistic symptom variance. The findings in this study give support to this lower symptom variance within 22qIIDS, with high scores in the social interaction and communication scales, and low scores on ritualistic behaviour on the Mini PAS-ADD.

We found higher scores on psychopathology in the deterioration group and less psychopathology in the stable low IQ group. In a cohort of 75 children with non-specific ID, Koskentausta et al. (2007), found more psychopathology in moderately intellectually disabled children when compared with severely/profoundly intellectually disabled children. Chadwick et al. (2008) also found a positive association between psychopathology and severity of ID in people with non-specific ID although the severity of the ID was also positively associated with autistic symptomatology. We did not conduct a longitudinal study, but retrospective data analysis showed fewer lifetime psychotic problems in the stable low IQ group. This is in agreement with the study of
Horovitz et al. (20II) who found a stable pattern of psychopathology in 74 adults with a severe to profound ID (in non-specific intellectual disabled adults) over a period of I year.

\section{Low FSIQ and deterioration}

The average premorbid FSIQ of $74.2( \pm 7.5)$ in our deterioration group is within the range of intelligence normally found in children and adults with 22qI IDS (Swillen et al. 2000; Chow et al. 2006; Vorstman et al. 2006). Cognitive deterioration in schizophrenia is a common finding (Becker et al. 2010); however, in our study we found a more severe decline in intellectual functioning compared with cognitive deterioration typically found in schizophrenia (Russell et al. I997; Seidman et al. 2006). Low functioning is noted on all Vineland domains demonstrating that not only verbal IQ is declined as seen in earlier research in 22qIIDS (Woodin et al. 200I). Our data show a strong positive correlation between psychotic problems during lifetime and deterioration in 22qIIDS $(r=0.62 \mathrm{I}$, $P=0.000$ ). There was no significant correlation between deterioration and current psychotic problems according to the Mini PAS-ADD score. Therefore we presume a causal relationship between lifetime psychosis and deterioration. To the best of our knowledge only 2 case reports have reported the phenomenon of severe cognitive deterioration in adult 22qIiDS (Evers et al. 2006, 2009). Duijff et al. reported in children with 22qIIDS between 5.5 and 9.5 years old a mean significant decline of 9.7 FSIQ points. Ten out of 29 children showed an absolute decline in cognitive raw scores between ages 7.5 and 9.5 year (Duijff et al. 2012). Gothelf et al. (2005) observed a cognitive deterioration in 22qIIDS, during childhood. This deterioration was Io points in verbal IQ with a strong correlation between the low activity Catechol-O-MethylTransferase (COMT) genotype, psychosis and deterioration. The relation between 22 qIIDS and psychosis has received attention in recent literature, where particularly COMT and Proline Dehydrogenase (PRODH) genes, both located in the deleted region, have been investigated (Raux et al. 2007; Boot et al. 20I Ic; da Silva Alves et al. 20II; de Koning et al. 2012). Haplo-insufficiency of COMT and/or PRODH genes could be a factor in 
the process of cognitive deterioration. We found a very high prevalence of lifetime history of psychotic problems (95\%) in the deterioration group, compared with the stable low IQ group ( $15 \%$ ) and compared with previous findings of up to $30 \%$ in people with 22qIIDS as a whole (Bassett et al. 2003). In our study gender differences were found with the female patients in the deterioration group showing more aggression and being particularly more vulnerable to develop a psychotic disorder when compared with the stable low IQ group. Gender differences in 22qIIDS have been described before. Kates et al. (2006) suggested that COMT polymorphism may have a gender modulating effect in determining the neuroanatomical phenotype. Antshel et al. (2005) found in a cohort of children that boys may be more cognitively affected than girls and a negative association between age and cognitive functioning in girls with 22qIIDS but not in boys. Also Boot et al. found indications of a slower dopamine metabolism in female patients (Boot et al. 20Ira). Oestrogens down-regulate COMT activity, resulting in a lower COMT and higher dopaminergic activity in women compared with men (Chen et al. 2004). Therefore, effects of COMT haplo-insufficiency may differentially affect men and women in with 22qIIDS (Harrison \& Tunbridge 2008).

In the analysis we looked for other possible explanations for the observed decline. Medication could be as one explanation for this decline; however, we found no differences between the two groups. Also a Spearman's rho correlation coefficient showed no significant level of correlation between present IQ and use of antipsychotics. Active psychopathology can have an impact on cognitive functioning and in the intellectual decline group we observe a significant higher proportion in depressive, anxiety, psychotic and unspecified problems (the latter two still significant after Bonferroni correction). Depression, for instant, is known to have a serious impact on daily functioning and it can be expected to influence scores on the Vineland-screener. To determine if active psychopathology is correlated with the present FSIQ we performed a Pearson productmoment correlation coefficient between Mini PASADD scores for depression, psychosis, anxiety and unspecified problems with present FSIQ. None of them showed a significant correlation. At this moment we presume a continuous, degenerative process having a stable and severely impairing impact on cognition and mental health.

\section{Strength and limitations}

This is the first report addressing adult patients with 22qIIDS and moderate to severe ID. To date, most studies in 22qIIDS concern children, adolescents and young adults. Also, subjects with moderate to severe ID are often excluded from studies therefore current literature on 22qIIDS may not representative of the 22 qIIDS. Gaining more insight into possible prognostic outcomes is in our opinion very important. This study, however has some limitations. Although the sample size is relatively large and the first for this specific subgroup of people with 22qIIDS, it is still small from a methodological point of view. Additionally, most participants were referred by psychiatric services or ID physicians, which makes the study accessible to ascertainment bias. Because of the low level of intellectual functioning we were unable to measure intelligence with standard intelligence tests. Premorbid intellectual functioning was obtained retrospectively from patient records. Therefore, premorbid functioning was established with different IQ instruments. Ideally, comparison of premorbid with present functioning is done with the same instruments. However, to our knowledge, there are no instruments that can measure mild ID and severe or profound disabilities making comparison possible. Establishing adaptive functioning with Vineland-Screener and afterwards making an estimation of present functioning was in our opinion the best choice.

In this study we presented a series of 33 patients who function at a low intelligence level. Some of them functioned already at young age at that low level, were others declined during adulthood. Although an IQ below 55 was thought to be relatively uncommon, but reported (Gerdes et al. 1999), we showed that it may be more common than expected. 22qIIDS as a diagnosis should be considered when patients display intellectual decline, especially when accompanied by psychosis. Conditions that are relative uncommon in 22qIIDS, such as polymicrogyria should not impede this (Robin et al. 2006). Our results suggest that those adults with 
22qIIDS that gradually deteriorate cognitively are highly likely to suffer from psychotic episodes during adult life, whereas those with a premorbid low IQ do not show the increased rates of psychosis that usually is seen in 22qIIDS.

The presence of psychosis and cognitive deterioration suggests a Dementia Praecox like picture as described by Kraepelin (Kraepelin I90I).

This psychotic disorder was described as a neurodegenerative process resulting in a dementialike condition. The cognitive deterioration we found in our 22qIIDS sample may be more severe and suggests a neurodegenerative process involving genes located at $22 \mathrm{qI}$.

More attention should be paid to psychiatric examination of 22 qI IDS subjects with moderate to severe ID. Longitudinal studies, including adult ages are needed to gain more insight in the behavioural, cognitive and psychiatric problems of this specific subgroup.

\section{Acknowledgements}

We thank the participating patients, their parents and their caregivers for participating in this study.

\section{Conflict of interest}

The authors declare that they have no conflict of interest.

\section{References}

Achenbach T. M. \& Rescorla L. A. (2003) Manual for the ASEBA Adult Forms E Profiles, Trans, Research Center for Children, Youth \& Families. Burlington, VT.

Adams D. \& Oliver C. (2010) The relationship between acquired impairments of executive function and behaviour change in adults with Down syndrome. Fournal of Intellectual Disability Research 54, 393-405.

Antshel K. M., AbdulSabur N., Roizen N., Fremont W. \& Kates W. R. (2005) Sex differences in cognitive functioning in velocardiofacial syndrome (VCFS). Developmental Neuropsychology 28, 849-69.

Antshel K. M., Fremont W., Roizen N. J., Shprintzen R., Higgins A. M., Dhamoon A. et al. (2006) ADHD, major depressive disorder, and simple phobias are prevalent psychiatric conditions in youth with velocardiofacial syndrome. Fournal of the American Academy of Child and Adolescent Psychiatry 45, 596-603.

Antshel K. M., Aneja A., Strunge L., Peebles J., Fremont W. P., Stallone K. et al. (2007) Autistic spectrum disorders in velo-cardio facial syndrome (22qIi.2 deletion). fournal of Autism and Developmental Disorders 37, I776-86.

Antshel K. M., Fremont W. \& Kates W. R. (2008) The neurocognitive phenotype in velo-cardio-facial syndrome: a developmental perspective. Developmental Disabilities Research Reviews 14, 43-5I.

Arnold P. D., Siegel Bartelt J., Cytrynbaum C., Teshima I. \& Schachar R. (200I) Velo-cardio-facial syndrome: implications of microdeletion 22qI I for schizophrenia and mood disorders. American fournal of Medical Genetics 105, 354-62.

Bassett A. S., Chow E. W., AbdelMalik P., Gheorghiu M., Husted J. \& Weksberg R. (2003) The schizophrenia phenotype in 22qI I deletion syndrome. The American Fournal of Psychiatry 160, 1580-6.

Becker H. E., Nieman D. H., Wiltink S., Dingemans P. M., van de Fliert J. R., Velthorst E. et al. (2010) Neurocognitive functioning before and after the first psychotic episode: does psychosis result in cognitive deterioration? Psychological Medicine 40, I599-606.

Boot E., Booij J., Abeling N., Meijer J., da Silva Alves F., Zinkstok J. et al. (2011a) Dopamine metabolism in adults with 22qII deletion syndrome, with and without schizophrenia - relationship with COMT Valıo8/ I58Met polymorphism, gender and symptomatology. fournal of Psychopharmacology 25, 888-95.

Boot E., Booij J., Abeling N., Meijer J., da Silva Alves F., Zinkstok J. et al. (20IIb) Dopamine metabolism in adults with 22qI I deletion syndrome, with and without schizophrenia - relationship with COMT Val(I)/(I)Met polymorphism, gender and symptomatology. Fournal of Psychopharmacology 25, 888-95.

Boot E., Booij J., Zinkstok J. R., Baas F., Swillen A., Owen M. J. et al. (20IIC) COMT Val(I58) met genotype and striatal $\mathrm{D}(2 / 3)$ receptor binding in adults with 22qII deletion syndrome. Synapse (New York, N.Y.) 65, 967-70.

Bruining H., de Sonneville L., Swaab H., de Jonge M., Kas M., van Engeland H. et al. (2010) Dissecting the clinical heterogeneity of autism spectrum disorders through defined genotypes. PLoS ONE 5, ero887.

Chadwick O., Kusel Y. \& Cuddy M. (2008) Factors associated with the risk of behaviour problems in adolescents with severe intellectual disabilities. Fournal of Intellectual Disability Research 52, 864-76.

Chen J., Lipska B. K., Halim N., Ma Q. D., Matsumoto M., Melhem S. et al. (2004) Functional analysis of genetic variation in catechol-O-methyltransferase

(C) 20I4 MENCAP and International Association of the Scientific Study of Intellectual and Developmental Disabilities and John Wiley \& Sons Ltd 
(COMT): effects on mRNA, protein, and enzyme activity in postmortem human brain. American fournal of Human Genetics 75, 807-21.

Chow E. W., Watson M., Young D. A. \& Bassett A. S. (2006) Neurocognitive profile in 22qI I deletion syndrome and schizophrenia. Schizophrenia Research 87, 270-8.

De Smedt B., Devriendt K., Fryns J. P., Vogels A., Gewillig M. \& Swillen A. (2007) Intellectual abilities in a large sample of children with Velo-Cardio-Facial Syndrome: an update. Fournal of Intellectual Disability Research 5I, 666-70.

Devine M., Taggart L. \& McLornian P. (2010) Screening for mental health problems in adults with learning disabilities using the Mini PAS-ADD Interview. British fournal of Learning Disabilities 4, 252-8.

Duijff S. N., Klaassen P. W., de Veye H. F., Beemer F. A., Sinnema G. \& Vorstman J. A. (20I2) Cognitive development in children with 22qII.2 deletion syndrome. The British fournal of Psychiatry: The fournal of Mental Science 200, 462-8.

Evers L. J., Vermaak M. P., Engelen J. J. \& Curfs L. M. (2006) The velocardiofacial syndrome in older age: dementia and autistic features. Genetic Counseling (Geneva, Switzerland) 17, 333-40.

Evers L. J., De Die Smulders C. E., Smeets E. E., Clerkx M. G. \& Curfs L. M. (2009) The velo-cardio-facial syndrome: the spectrum of psychiatric problems and cognitive deterioration at adult age. Genetic Counseling (Geneva, Switzerland) 20, 307-15.

Feinstein C., Eliez S., Blasey C. \& Reiss A. L. (2002) Psychiatric disorders and behavioral problems in children with velocardiofacial syndrome: usefulness as phenotypic indicators of schizophrenia risk. Biological Psychiatry 5I, 3I2-I8.

Gerdes M., Solot C., Wang P. P., Moss E., LaRossa D., Randall P. et al. (1999) Cognitive and behavior profile of preschool children with chromosome 22qII.2 deletion. American fournal of Medical Genetics 85, I27-33.

Gothelf D., Presburger G., Zohar A. H., Burg M., Nahmani A., Frydman M. et al. (2004) Obsessivecompulsive disorder in patients with velocardiofacial (22qII deletion) syndrome. American fournal of Medical Genetics. Part B, Neuropsychiatric Genetics 126, 99-105.

Gothelf D., Eliez S., Thompson T., Hinard C., Penniman L., Feinstein C. et al. (2005) COMT genotype predicts longitudinal cognitive decline and psychosis in 22qII.2 deletion syndrome. Nature Neuroscience 8, I500-2.

Gothelf D., Frisch A., Michaelovsky E., Weizman A. \& Shprintzen R. J. (2009) Velo-Cardio-Facial-Syndrome. fournal of Mental Health Research in Intellectual Disabilities 2, I49-67.

Harrison P. J. \& Tunbridge E. M. (2008) Catechol-Omethyltransferase (COMT): a gene contributing to sex differences in brain function, and to sexual dimorphism in the predisposition to psychiatric disorders.

Neuropsychopharmacology 33, 3037-45.

Henry J. C., van Amelsvoort T., Morris R. G., Owen M. J., Murphy D. G. \& Murphy K. C. (2002) An investigation of the neuropsychological profile in adults with velo-cardio-facial syndrome (VCFS). Neuropsychologia 40, $47 \mathrm{I}-8$.

Horovitz M., Matson J. L., Sipes M., Shoemaker M., Belva B. \& Bamburg J. W. (20II) Incidence and trends in psychopathology symptoms over time in adults with severe to profound intellectual disability. Research in Developmental Disabilities 32, 685-92.

Kates W. R., Antshel K. M., Abdulsabur N., Colgan D., Funke B., Fremont W. et al. (2006) A gendermoderated effect of a functional COMT polymorphism on prefrontal brain morphology and function in velocardio-facial syndrome (22qII.2 deletion syndrome). American fournal of Medical Genetics. Part B, Neuropsychiatric Genetics I4IB(3), 274-80.

de Koning M. B., Boot E., Bloemen O. J., van Duin E. D., Abel K. M., de Haan L. et al. (20I2) Startle reactivity and prepulse inhibition of the acoustic startle response are modulated by catechol-O-methyltransferase $\mathrm{Val}(\mathrm{I} 58)$ Met polymorphism in adults with 22qII deletion syndrome. Fournal of Psychopharmacology 26, I $548-60$.

Koskentausta T., Iivanainen M. \& Almqvist F. (2007) Risk factors for psychiatric disturbance in children with intellectual disability. Fournal of Intellectual Disability Research 5I, 43-53.

Kraepelin E. (I90I) A general view of dementia praecox, Brownrigg AE (trans). The American fournal of Insanity 58, I2 I-32.

Kraijer D. W. \& Plas J. J. (2006) Handboek psychodiagnostiek en beperkte begaafdheid, Harcourt Assesment B.V., Amsterdam.

McDonald McGinn D. M. \& Sullivan K. E. (20II) Chromosome 22qII.2 deletion syndrome (DiGeorge syndrome/velocardiofacial syndrome). Medicine 90, I-I8.

McDonald-McGinn D. M., Kirschner R., Goldmuntz E., Sullivan K., Eicher P., Gerdes M. et al. (1999) The Philadelphia story: the 22qII.2 deletion: report on 250 patients. Genetic Counseling Io, II-24.

Murphy K. C., Jones L. A. \& Owen M. J. (1999) High rates of schizophrenia in adults with velo-cardio-facial syndrome. Archives of General Psychiatry 56, 940-5.

Niklasson L. \& Gillberg C. (20I0) The neuropsychology of 22qI I deletion syndrome. A neuropsychiatric study of Ioo individuals. Research in Developmental Disabilities 31, I85-94.

Niklasson L., Rasmussen P., Oskarsdottir S. \& Gillberg C. (2009) Autism, ADHD, mental retardation and behavior problems in 100 individuals with 22qII deletion syndrome. Research in Developmental Disabilities 30, 763-73.

(C) 20I4 MENCAP and International Association of the Scientific Study of Intellectual and Developmental Disabilities and John Wiley \& Sons Ltd 
Oskarsdottir S., Vujic M. \& Fasth A. (2004) Incidence and prevalence of the 22qI I deletion syndrome: a population-based study in Western Sweden. Archives of Disease in Childhood 89, I48-5I.

Papolos D. F., Faedda G. L., Veit S., Goldberg R., Morrow B., Kucherlapati R. et al. (I996) Bipolar spectrum disorders in patients diagnosed with velo-cardiofacial syndrome: does a hemizygous deletion of chromosome 22qI result in bipolar affective disorder? The American fournal of Psychiatry 153, I54I-7.

Philip N. \& Bassett A. (20II) Cognitive, behavioural and psychiatric phenotype in 22qII.2 deletion syndrome. Behavior Genetics 4I, 403-I2.

Prosser H., Moss S., Costello H., Simpson N., Patel P. \& Rowe S. (1998) Reliability and validity of the Mini PASADD for assessing psychiatric disorders in adults with intellectual disability. Fournal of Intellectual Disability Research 42 (Pt 4), 264-72.

Raux G., Bumsel E., Hecketsweiler B., van Amelsvoort T., Zinkstok J., Manouvrier-Hanu S. et al. (2007) Involvement of hyperprolinemia in cognitive and psychiatric features of the 22qII deletion syndrome. Human Molecular Genetics 16, 83-91.

Robin N. H., Taylor C. J., McDonald-McGinn D. M., Zackai E. H., Bingham P., Collins K. J. et al. (2006) Polymicrogyria and deletion 22qII.2 syndrome: window to the etiology of a common cortical malformation. American fournal of Medical Genetics. Part A 140, 2416-25.

Russell A. J., Munro J. C., Jones P. B., Hemsley D. R. \& Murray R. M. (I997) Schizophrenia and the myth of intellectual decline. The American fournal of Psychiatry 154, 635-9.

Scholte E., van Duijn V. G., Dijkxhoorn Y., Noens I. \& van Berckelaer-Onnes I. A. (2008) Vineland Screener o-6 jaar, Trans. PITS, Leiden, the Netherlands.

Seidman L. J., Buka S. L., Goldstein J. M. \& Tsuang M. T. (2006) Intellectual decline in schizophrenia: evidence from a prospective birth cohort 28 year follow-up study. fournal of Clinical and Experimental Neuropsychology 28, 225-42.

Shprintzen R. J. (2008) Velo-cardio-facial syndrome: 30 years of study. Developmental Disabilities Research Reviews I4, 3-10.

Shprintzen R. J., Higgins A. M., Antshel K., Fremont W., Roizen N. \& Kates W. (2005) Velo-cardio-facial syndrome. Current Opinion in Pediatrics 17, 725-30. da Silva Alves F., Boot E., Schmitz N., Nederveen A., Vorstman J., Lavini C. et al. (20II) Proton magnetic resonance spectroscopy in 22qII deletion syndrome. PLOS ONE 6, e21685.

Sparrow S. S., Carter A. C., Cicchetti D. V., Scholte E., van Duijn G., Dijkxhoorn Y. et al. (2008) Vineland Screener 0-6 jaar, Trans. PITS, Leiden, the Netherlands.

Stevens A. F. \& Murphy K. C. (2005) Behavioral and psychiatric disorders in velo-cardio-facial syndrome. In: Velo-cardio-facial Syndrome, a Model for Understanding Microdeletion Disorders (eds K. C. Murphy \& P. J. Scambler), pp. 135-46. Cambridge University Press, Cambridge.

Swillen A., Devriendt K., Legius E., Eyskens B., Dumoulin M., Gewillig M. et al. (1997) Intelligence and psychosocial adjustment in velocardiofacial syndrome: a study of 37 children and adolescents with VCFS.

fournal of Medical Genetics 34, 453-8.

Swillen A., Vandeputte L., Cracco J., Maes B., Ghesquiere P., Devriendt K. et al. (I999)

Neuropsychological, learning and psychosocial profile of primary school aged children with the velo-cardio-facial syndrome (22qI I deletion): evidence for a nonverbal learning disability? Child Neuropsychology 5, 230-4I.

Swillen A., Vogels A., Devriendt K. \& Fryns J. P. (2000) Chromosome 22qI I deletion syndrome: update and review of the clinical features, cognitive-behavioral spectrum, and psychiatric complications. American fournal of Medical Genetics 97, I28-35.

van Duijn G., Dijkxhoorn Y., Noens I., Scholte E. \& van Berckelaer Onnes I. (2009) Vineland Screener O-I2 years research version (NL). Constructing a screening instrument to assess adaptive behaviour. International fournal of Methods in Psychiatric Research 18, IIO-17.

Vorstman J. A., Morcus M. E., Duijff S. N., Klaassen P. W., Heineman-de Boer J. A., Beemer F. A. et al. (2006) The 22qII.2 deletion in children: high rate of autistic disorders and early onset of psychotic symptoms. Fournal of the American Academy of Child and Adolescent Psychiatry 45, IIO4-I3.

Woodin M., Wang P. P., Aleman D., McDonald-McGinn D., Zackai E. \& Moss E. (200I) Neuropsychological profile of children and adolescents with the 22qII.2 microdeletion. Genetics in Medicine 3, 34-9.

Wulffaert J., Van Berckelaer Onnes I. A. \& Scholte E. M. (2009) Autistic disorder symptoms in Rett syndrome. Autism: The International fournal of Research and Practice 13, 567-8I

Accepted I2 December 2013

(C) 2014 MENCAP and International Association of the Scientific Study of Intellectual and Developmental Disabilities and John Wiley \& Sons Ltd 